$$
\begin{aligned}
& \text { ATR }-80-7873-6 \\
& \text { DE82 } 007217
\end{aligned}
$$

\title{
ALTERNATIVE ECONOMIC EVALUATION MEASURES FOR SOLAR INDUSTRIAL I/ PROCESS HEAT
}

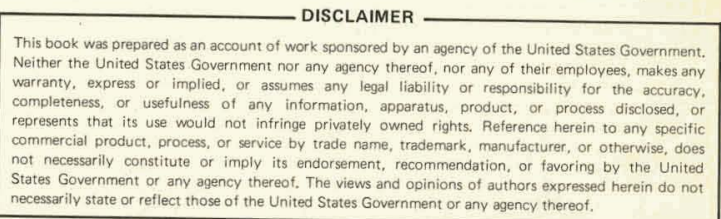

Prepared by

Energy and Resources Division

30 July 1980

Government Support Operations

THE AEROSPACE CORPORATION

E1 Segundo, California 90256

\author{
Prepared for \\ THE DEPARTMENT OF ENERGY \\ Solar Energy Division, DOE/SAN \\ Contract No. DE AC-03-80SF-10800
}




\section{DISCLAIMER}

This report was prepared as an account of work sponsored by an agency of the United States Government. Neither the United States Government nor any agency Thereof, nor any of their employees, makes any warranty, express or implied, or assumes any legal liability or responsibility for the accuracy, completeness, or usefulness of any information, apparatus, product, or process disclosed, or represents that its use would not infringe privately owned rights. Reference herein to any specific commercial product, process, or service by trade name, trademark, manufacturer, or otherwise does not necessarily constitute or imply its endorsement, recommendation, or favoring by the United States Government or any agency thereof. The views and opinions of authors expressed herein do not necessarily state or reflect those of the United States Government or any agency thereof. 


\section{DISCLAIMER}

Portions of this document may be illegible in electronic image products. Images are produced from the best available original document. 
FOREWORD

This report presents a discussion of the various measures often used in private industry to assist managers in assessing new investments. The use of these evaluation measures is illustrated by analysis of an assumed solar industrial process heat (IPH) project.

The study was undertaken as part of Aerospace's task, Systems Eng ineerIng Studies, for the Advanced Central Recelver Development Program, to develop the methodology for conducting economic sensitivity studies of typical IPH projects which utilize solar thermal energy.

The study was conducted by The Aerospace Corporation under Contract No. DE AC-03-80SF-10800 under the cognizance of Mr. R. Hughey, Director of the Division of Solar Energy, and the general direction of Dr. S. D. Elliott, Program Manager, DOE/SAN. The report was written by L. Schelhorse and J. Clair Ellis of the Economic Evaluation Directorate at The Aerospace Corporation.

This report is being 1ssued by the Energy and Resources Division of The Aerospace Corporation. Mr. S. D. Huffman is the General Manager, and Mr. H. Bernstein is the Group Director. Dr. P. Mathur is the Principal Investigator on this contract. 


\title{
ALTERNATIVE ECONOMIC EVALUATION MEASURES \\ FOR SOLAR INDUSTRIAL PROCESS HEAT
}

\author{
by Larry $D$. Schelhorse
}

and

J. Clair Ellis

\section{INTRODUCTION}

Several measures are often used to assist decision-makers in evaluating the economic merit of solar energy projects. This paper describes and compares the most commonly used measures. An example is given to illustrate the economic evaluation measures and the results are applied to a solar industrial process heat project.

Four economic measures have been identified which are most widely used:

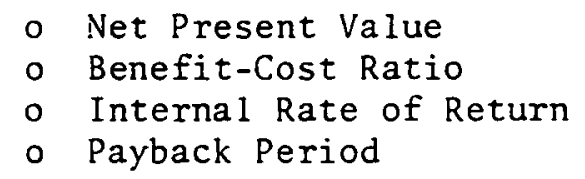

All of these measures are used to summarize estimates of the benefits and costs of investment projects over time. All but payback period summarize those economic consequences over the entire project lifecycle. When consistently applied, the measures provide objective criteria to aid in the decision to accept or reject projects which are independent of one another. Also, the measures can be used to rank projects which are mutually exclusive because of limits on capital funds, land, minerals, or other required production inputs.

The perspective analyzed in this paper is that of the privately-owned firm. The objective of the firm is assumed to be the maximization of current wealth (market value), which is the expected present value of current and future after-tax net cash flows. The discount rate used in these present value calculations is assumed to be the after-tax cost of capital to the firm. The project benefits are measured by cash inflows and project costs by cash outflows. 


\section{DEFINITION AND ILLUSTRATION OF THE ALTERNATIVE ECONOMIC MEASURES}

The equations in Table 1 define the alternative economic measures, which are further described below. The net present value (NPV) as of time $t=0$, is the sum of the present values of the net cash flows occurring in each time period through time $t=N$, where $N$ is the expected project lifetime. The present values of those future cash flows are reduced, or discounted, according to their time of occurrence and the discount rate per unit of time, $k$. Time is generally measured in years. The discount rate measures the cost of using capital funds in that project, rather than in competing projects.

The benefit-cost ratio $(B / C)$ is the summed present values of the benefits divided by the summed present values of the costs. Its calculation requires that the cash inflows and outflows be clearly differentiated rather than just summed in each time period as for NPV. The internal rate of return (IRR) of an investment project is a discount rate for which the project's NPV is equal to zero. It is possible, although not common, for multiple values for the IRR to exist. The payback period (PBP) is generally defined as the number of time periods required to recover the initial investment from net cash flows. Although it is not typically done, the net cash flows can be discounted to calculate a discounted payback period, PBP

disc.

The circumstances under which the alternative measures are most useful, as well as certain advantages and disadvantages of each measure, are described below. The net present value of individual projects generally provides the best measure of their incremental effects on the current wealth of the firm. Thus, if a project's NPV is greater than zero, it will cause an increase in wealth and should be undertaken. A project with a negative NPV will decrease wealth. Projects which are mutually exclusive due to limitations on resources other than capital funds can be ranked by NPV. Then the projects with the highest NPV can be adopted to the limits of the available resources. When capital investment funds are limited, however, the wealth maximizing objective is not applicable and neither NPV nor any of the other measures provides an objective standard.

Because of its mathematical definition, the benefit-cost ratio will always be greater than one when the NPV is positive. Therefore, an alternative acceptance criterion is that $B / C$ be greater than one. Also, B/C can provide a general measure of the proportionate difference between benefits and costs, and, therefore, is often used to rank mutually exclusive projects. That ranking should be limited to projects having similar sources and uses of cash, however, because the absolute magnitude of $B / C$ is sensitive to the definition of those cash flows. 
NET PRESENT VALUE, NPV $=\sum_{t=0}^{N}\left(B_{t}-C_{t}\right)(1+k)^{-t}$

BENEFIT-COST RATIO, $B / C=\sum_{t=0}^{N} B_{t}(1+k)^{-t} / \sum_{t=0}^{N} C_{t}(1+k)^{-t}$

INTERNAL RATE OF RETURN, IRR $=r \mid 0=\sum_{t=0}^{N}\left(B_{t}-C_{t}\right)(1+r)^{-t}$

SIMPLE PAYBACK PERIOD, PBP $=n \mid 0=\sum_{t=0}^{n}\left(B_{t}-C_{t}\right)$

DISCOUNTED PAYBACK PERIOD, $\underset{\text { disc }}{\text { PBP }}=n \mid 0=\sum_{t=0}^{n}\left(B_{t}-C_{t}\right)(1+k)^{-t}$

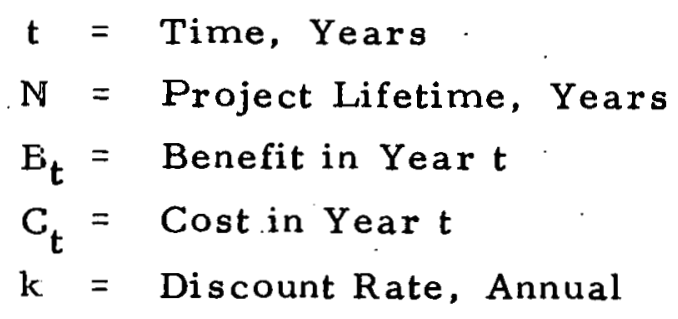


Typical investment projects which involve an initial cash outlay with positive net cash flows thereafter can be evaluated by their internal rate of return. Those projects with IRR greater than the discount rate should be undertaken. Projects with alternating positive and negative cash flows have multiple values for IRR and should be evaluated using other measures. If capital funds are constrained, it is often useful to rank projects according to their IRR. Those with the highest IRR should be undertaken first, but no objective criterion exists for determining how many of the projects should be accepted. For mutually exclusive projects, the rankings by IRR do not reliably coincide with those by NPV.

Unlike the other measures, payback period does not summarize a project's cash flow over its entire life cycle. Also, it does not reliably measure changes in wealth as it ignores cash flows beyond those necessary to recover the initial investment. The value of a project, however, depends on how much it returns after the investment is recovered. PBP is best used as a general screening criterion for small or routine projects. In its simpler form, it is easy to calculate. Also, for routine projects, experience may reveal a consistent relationship between PBP and changes in wealth.

Table 2 illustrates various relationships among the alternative economic measures. Three projects are described, each involving an initial outlay of $\$ 1000$ followed by six years of positive net cash flows. The projects' net present values are shown to be sensitive to the discount rate. At a discount rate of ten percent all of the projects have positive NPV's and should be accepted if they are independent. If they are mutually exclusive, then project $B$ is preferred because of its larger NPV. At higher discount rates the rankings are changed to favor project $C$. At a discount rate of twenty percent project $B$ should not be accepted because of its negative NPV. The comparisons of benefit-cost ratios yields the same results.

Project $A$ and project $C$ have internal rates of return greater than twenty percent. Therefore, as shown previously by their NPV's, they should be accepted at any of the discount rates presented. Project $B$ should only be accepted if the discount rate is less than 19.7 percent. Although project $C$ has the highest IRR and project $B$ the lowest, the comparison of NPV's shows that project B should be preferred at a sufficiently low discount rate. However, if capital funds are constrained, project $C$ should be accepted first, then followed by project $A$ if additional projects are desired.

Project $A$ has the shortest payback period. However, the other measures indicate that project $A$ should not be the most preferred under any of the circumstances presented. In this example the use of the PBP measure would not accomplish the firm's objective of wealth maximization. 


Year
0
1
2
3
4
5
6

\begin{tabular}{rrr} 
Project A & $\frac{\text { Net Cash Flow }(\$)}{\text { Project B }}$ & Project C \\
\cline { 2 - 3 }-1000 & -1000 & -1000 \\
500 & 100 & 320 \\
400 & 200 & 320 \\
300 & 300 & 320 \\
100 & 400 & 320 \\
100 & 500 & 320 \\
100 & 600 & 320
\end{tabular}

\section{Economic \\ Measures}

Net Present Value ( $\$$ )
@ 10\%
@ 15\%
@ 20\%

266

404

394

142

172

211

38

$-9$

64

Benefit-Cost Ratio
@ 10\%
@ 15\%
@ 20\%

1.27

1. 40

1. 39

1.14

1.17

1. 21

1.04

0.99

1.06

Internal Rate of Return (\%)

22. 1

19. 7

22.6

Payback Period (years)

\section{Simple}

Discounted@10\%

$\begin{array}{lll}2.3 & 4.0 & 3.1 \\ 3.0 & 4.8 & 3.9\end{array}$


Table 3 presents sample data for an economic comparison of industrial process heat from solar, oil, gas, and coal energy sources. The object of this example is to illustrate the use of the economic evaluation measures in the decision of a firm to replace its conventional IPH sources with a solar facility. The costs of the solar facility are presented. The benefits of the solar facility are taken to be the reduced expenditures on the conventional fuel displaced.

The solar plant is assumed to cost 67.068 million dollars initially and be capable of producing 1.212 trillion Btu per year for 30 years thereafter. The recurring solar plant costs include operations and maintenance (O\&M), property taxes, and insurance. The prices for conventional fuels are presented for 1979 and are assumed to increase at the rates presented in real terms (that is, in addition to the general inflation rate).

The firm is assumed to have financial characteristics typical of moderateto-large industrial firms. The firm is capitalized with both debt and equity, with real debt costs of 3.25 percent and real equity costs of 8.00 percent. The firm is assumed to be in the 50 percent income tax bracket. The resulting cost of capital of 4.5 percent is used as the discount rate.

The results for the year 2000 and the conclusions of the solar IPH example are presented in Table 4 and are further described below. Based on the assumptions used in this example, the solar IPH plants used to displace oil and gas fuels have positive net present values for the year 2000. Also, the benefit-cost ratios are greater than one and the internal rates of return are higher than the cost of capital, which was $4.5 \%$ in this example. All three measures indicate that those solar plants should be built. Similarly, all three measures indicate that the solar plant which displaces coal should not be built.

In this example, NPV, B/C, and IRR all provide the same decision recommendations. Also, if the solar plants were mutually exclusive for some reason, all three measures provide consistent ranking among the plants, with the oil-displacing plant being preferred. The payback period measure provides a similar ranking among the plants in this example. However. the long PBP for the first two plants might incorrectly indicate that they should not be built. 


\section{COST ASSUMPTIONS}

Solar Plant Installed Cost

$67.068 \times 10^{6} \quad 1979 \$$

Solar Plant $0 \& M$ Costs

$2.012 \times 10^{6} 1979 \$ /$ year

Solar IPH Production

$1.212 \times 10^{12} \mathrm{Btu} /$ year

Solar Plant Lifetime

30 years

Oil Price, 1979

2. $381979 \$ /$ Million Btu

Oil Price Escalation Rate, Real

3. $7 \% /$ year

Gas Price, 1.979

3. $141979 \$ /$ Million Btu

Gas Price Escalation Rate, Real

Coal Price, 1979

1. $9 \% /$ year

Goal Price Escalation Rate, Real 5.6\%/year through 1985

$0.9 \% /$ year after 1985

FINANCIAL ASSUMPTIONS

$\begin{array}{ll}\text { General Rate of Inflation } & 8.00 \% \\ \text { Real Cost of Debt } & 3.25 \% \\ \text { Rəal Cost of Equity } & 8.00 \% \\ \text { Debt-Asset Ratio } & 55 \% \\ \text { Income Tax Rate } & 50 \% \\ \text { Investment Tax Credit Rate } & 10 \% \\ \text { Tax Depreciation Method } & \text { Straight-line, 30 years } \\ \text { Property Tax Rate } & 2 \% \\ \text { Insurance Cost Rate } & 0.4 \% \\ \text { Cost of Capital (calculated) } & 4.5 \%\end{array}$


Table 4

SOLAR IPH APPLICATION

ALTERNATIVE ECONOMIC MEASURES, YEAR 2000

$\frac{\text { RESULTS }}{\text { NPV }} . \quad \underline{B / C} \quad \frac{\text { IRR }}{(\%)} \quad \frac{\text { PBP }}{\text { (years) }}$

Solar vs. Oil

68.2

1.6

8. 7

11

Solar vs. Gas

4.5

1.0

4. 8

15

Solar vs: Coal

$-1.1$

0.9

3.5

17 